\title{
Place Attachment in Public Space Case Study: Hiraq Square Lhokseumawe Aceh - Indonesia
}

\author{
Bambang Karsono $^{1 *}$, Julaihi Wahid ${ }^{2}$, Yenny Novianti ${ }^{3}$, Nurhaiza ${ }^{4}$, Soraya M. H. ${ }^{5}$ \\ 1,2 Department of Architecture, Faculty of Built Environment, Universiti Malaysia Sarawak, Kuching, Malaysia \\ ${ }^{3,4,5}$ Department of Architecture, Faculty of Engineering, Universitas Malikussaleh., Lhokseumawe, Indonesia \\ "Corresponding author. Email: kbambang@ unimas.my
}

\begin{abstract}
Concerning the issue of place attachment, the research tends to observe the functional attachment, which will affect the level of attachment in Hiraq Square Lhokseumawe (HSL), a renowned public space among local people in the city of Lhokseumawe, Aceh, Indonesia. Place attachment is known as a process to unite people and specific space that can encourage the sense of place. It is also indicating the interrelation between physical features and its function. Through this process, the sense of a place can emerge. These concepts concentrate on the physical features and activities, together with the meanings affected by users, will establish the meaning and identity of the place. The research is conducted by applying an indirect method to simplify ordinary patterns and people-particular patterns of the place. Overall, 120 respondents in a particular area of HSL were questioned through a questionnaire survey, and ten kiosk operators were questioned. The findings indicate that people have a robust relationship with the local environment and appoint the significance of place as economics' dependence and recreational place. The level of functional attachment to HSL ranges from level 1 to level 3, whereas level 3 implicates a higher engagement in loyalty, goals, and obedience to the environment.
\end{abstract}

Keywords: Place attachment, public space, sense of place

\section{INTRODUCTION}

Robust relation that occurs between emotional and functional in a particular space or interrelation between people and particular places can arouse the sense of place; this occurrence is acknowledged as place attachment [1]. According to Relph [2], three components are needed taking into account in understanding a particular place, i.e., physical elements, activities and functions, and meanings or symbols. It clarifies that a particular place contains physical features, activity, and meaning. Canter [3] also has similar judgment that a place is a mixture of three features involving the activities, the concept of place, and the environment. In this study, place attachment designates the relationship between physical elements and its function also relationship among the people and a specific place; hence the meaning of a particular place can be emerged [4]. This study assumes that the effect of unsuitable physical modification may distress the meaning, and the attachment to the place will be slowly diminished. Place-based concepts and principles are used to examines this issue and focus on the physical elements, activities, and meanings gripped by the people is the strength to deliver the identity and the meaning of the place. The research stresses the elements of place attachment in investigating the relationship between psychological aspects and physical features of a particular place. Consequently, this research is designated to distinguish place attachment in Hiraq Square as a public space that is renowned among local people in Lhokseumawe, Aceh, Indonesia.

Hiraq Square Lhokseumawe (HSL) was chosen as a case study, a popular public open space located in the center of Lhokseumawe, a city in the Northern Aceh, Indonesia. Lhokseumawe is known as the second-largest city in Aceh Province after Banda Aceh. Lhokseumawe itself covers an area of $181.06 \mathrm{~km}^{2}$ and consists of 180,200 people as a recent number of the population inside the city. Being in between Banda Aceh and Medan, Lhokseumawe change becomes an important regional center for the economy of Aceh Province. The HSL itself covers an area of approximately $14,904 \mathrm{~m}^{2}$; its main function is as public space and located next to the Islamic Center Grand Mosque of Lhokseuamawe. Figure 1 show images of HSL which is well known by local people as a place for relaxing with family and became the most visited place during school holidays, while Table 1 indicates the daily activities conducted in the HSL and its surrounding. Lots of playgrounds and other facilities with improper arrangements can be found there starting from the afternoon until midnight. This research focuses on identifying the particular functional and emotional attachment of people in HSL. This study is significant in 
recognizing the localities within a particular place in the city as a local character and expressive among the people.

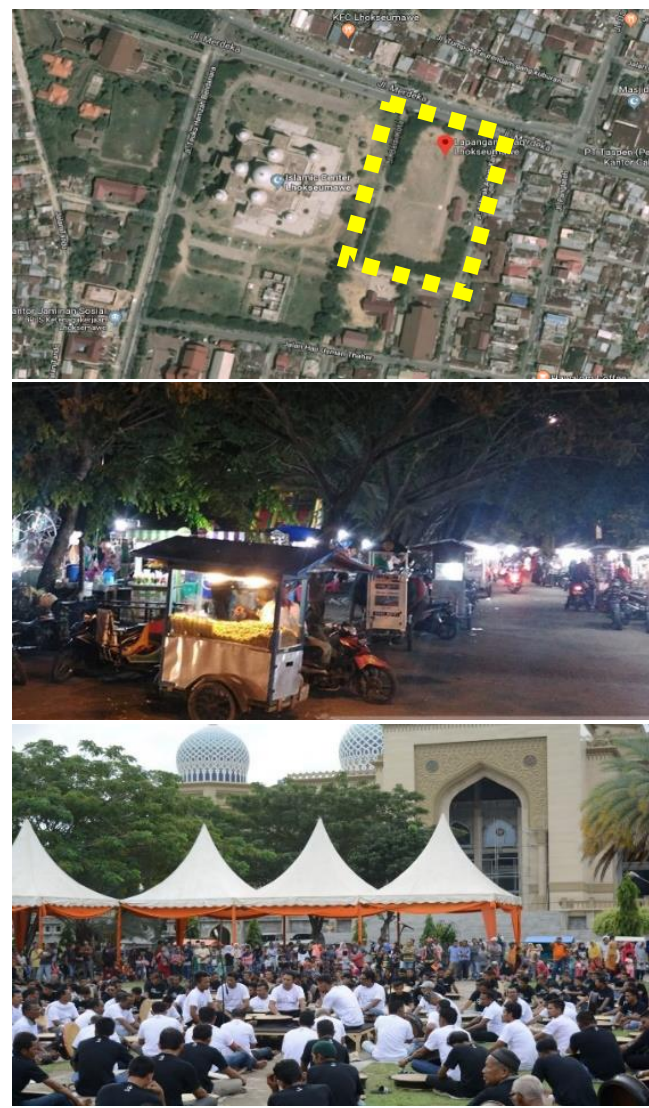

Figure 1 Atmosphere of HSL

\section{LITERATURE REVIEW}

In this research, place attachment is a key conception to reveal the phenomena of sense of place. The positive emotional attachment between people to their setting and environment can be understood as place attachment [5]. Place attachment emerges through the relationship between people to a particular place base on their satisfaction, experience, and value to that place [6]. The level of a successful neighborhood to become a place is determined by the emotional level of personal investment within the place [7]. Human perceptions of the place are also influenced by the psychological status of well-being, which produced from the access into particular places [8]. In the last three decades, interrelated concepts of place attachment and sense of place have overwhelmed the theory $[1,2,5]$. Various studies have been created in the last 15 years to discover these concepts empirically. A measurement process has been conducted to understand the quality of place by approaching how it is perceived and valued by society. Since urban environment objectives are to be used and perceived by society, therefore, it is notable that attention should be given to the predispose of place dimensions [9]. To discover such meaning of a place can be clarified through understanding the attachment of the place. This empirical study emphasis on measuring the intensity of attachment.

Table 1 Daily activities conducted in the HSL

\begin{tabular}{|c|c|c|c|}
\hline \multicolumn{2}{|c|}{ Time/Day } & Activities & \multirow{2}{*}{\begin{tabular}{l}
\multicolumn{1}{c}{ Space } \\
Pedestrian ways, \\
Open space, \\
Sidewalk corridor.
\end{tabular}} \\
\hline $7.00 \mathrm{am}-12.00 \mathrm{pm}$ & Monday - Friday & $\begin{array}{l}\text { Formal flag ceremony, doing sports, sitting, waiting for people, } \\
\text { watching people, preparation for selling food and drinks, walking } \\
\text { along the pedestrian ways, taking photos. }\end{array}$ & \\
\hline & Saturday - Sunday & $\begin{array}{l}\text { Doing sports, sitting, waiting people, watching people, preparation } \\
\text { for selling food and drinks, walking along the pedestrian ways, } \\
\text { taking photos. }\end{array}$ & $\begin{array}{l}\text { Pedestrian ways, } \\
\text { Open space, } \\
\text { Sidewalk corridor. }\end{array}$ \\
\hline & Atmosphere in general & \multicolumn{2}{|c|}{$\begin{array}{l}\text { Activities with moderate intensity mostly by local residents and primary school student } \\
\text { exercising }\end{array}$} \\
\hline \multirow[t]{3}{*}{$1.00-2.00 \mathrm{pm}$} & Monday - Friday & Street vendors/hawkres & Sidewalk corridor. \\
\hline & Saturday - Sunday & Street vendors/hawkers & Sidewalk corridor. \\
\hline & Atmosphere in general & \multicolumn{2}{|l|}{ Low intensity of activities } \\
\hline \multirow[t]{3}{*}{$3.00-7.00 \mathrm{pm}$} & Monday - Friday & $\begin{array}{l}\text { Street vendors/hawkers, children playing, doing sports, walking } \\
\text { along the pedestrian ways, taking photos. }\end{array}$ & $\begin{array}{l}\text { Pedestrian ways, } \\
\text { Open space, } \\
\text { Sidewalk corridor. }\end{array}$ \\
\hline & Saturday - Sunday & $\begin{array}{l}\text { Street vendors/hawkers, children playing, doing sports, walking } \\
\text { along the pedestrian ways, taking photos. }\end{array}$ & $\begin{array}{l}\text { Pedestrian ways, } \\
\text { Open space, } \\
\text { Sidewalk corridor. }\end{array}$ \\
\hline & Atmosphere in general & \multicolumn{2}{|c|}{$\begin{array}{l}\text { Moderate intensity activities, dominated by locals and children playing, however the activity } \\
\text { stopped when Azan Maghrib reverberated from the Masjid next to HSL }\end{array}$} \\
\hline \multirow[t]{3}{*}{$8.00-11.50 \mathrm{pm}$} & Monday - Friday & $\begin{array}{l}\text { Street vendors/hawkers, children playing, doing sports, walking } \\
\text { along the pedestrian ways, taking photos. Activities ended at around } \\
12.00 \text { midnight. }\end{array}$ & $\begin{array}{l}\text { Pedestrian ways, } \\
\text { Open space, } \\
\text { Sidewalk corridor. }\end{array}$ \\
\hline & Saturday - Sunday & $\begin{array}{l}\text { Street vendors/hawkers, children playing, doing sports, walking } \\
\text { along the pedestrian ways, taking photos. On weekends, visitors are } \\
\text { more crowded and activities ended at around } 12.00 \text { midnight. }\end{array}$ & $\begin{array}{l}\text { Pedestrian ways, } \\
\text { Open space, } \\
\text { Sidewalk corridor. }\end{array}$ \\
\hline & Atmosphere in general & \multicolumn{2}{|c|}{$\begin{array}{l}\text { High intensity activities at night, crowded with local residents and children playing, are more } \\
\text { crowded during weekends and public holidays. }\end{array}$} \\
\hline
\end{tabular}


Current studies describe the sense of place and place attachment by employing some variables to measure off attachments quantitatively, i.e., familiarity, the period of discourse, reliance, place of identity, sense of belonging, and sense of place [1,10-12]. To recognize the sense of place or sense to territories level, Shamai [11] recommend a set of measurement tool with seven-level criteria from the 0 (zero) to 6th level. The ratings itself are not exactly suitable for any type of place; it is flexible to be applied depend on the types of place (refer to Table 2). In this study, findings of ratings in the sense of place could help researchers identify the form and level of attachment in HSL.

Table 2 Sense of place level, according to Shamai [11]

\begin{tabular}{|c|l|l|}
\hline Level & \multicolumn{1}{|c|}{ Sense of place criteria } & \multicolumn{1}{c|}{ Keywords } \\
\hline 0 & Has no sense of place & No attachment \\
\hline 1 & Knowing being in place & Understanding Symbols, Knowing. \\
\hline 2 & Has a sense of belonging to the place & Sense of belonging; togetherness; sense of same fate; respected symbols \\
\hline 3 & Has attachment to the place & $\begin{array}{l}\text { Emotion; meaning; experience; symbol; identity; personality; } \\
\text { uniqueness; difference }\end{array}$ \\
\hline 4 & Understand the place goals & Share goals; loyalty; obedience \\
\hline 5 & Has a place engagement & $\begin{array}{l}\text { Commitment; engagement; behavior; investment of human resources in } \\
\text { group activities; actively involved. }\end{array}$ \\
\hline 6 & Sacrifice for the place. & Sacrifice; good commitment \\
\hline
\end{tabular}

\section{METHODOLOGY}

To measure perception, researchers mostly implement two methods, namely, direct or indirect assessment [13,14]. The direct method consists of the phenomenology approach to examine and designate the human circumstances and activities that happen voluntarily in daily life [16]. The goal of this method is to recognize the uniqueness of the place qualitatively in a holistic way. On the other side, indirect methods are including self-reports processes such as questionnaires survey, interview, description checklist, and time-sampling [17].

The indirect method was applied in this study by using questionnaires, interviews, observation techniques to explain activity patterns and specific patterns of human movement in the place. One hundred twenty respondents were involved in the survey that divides into two categories, namely mobile users (60) and static users (60). The static users mostly are sidewalk vendors who have a crucial role. Meanwhile, mobile users commonly are visitors and local residents who came to pay a visit to HSL periodically. At the same time in-depth interview has been taken to 10 (ten) of respondents in the study area. All respondents indicate the main users of the study area, which consist of various groups of ages between 18-24 and 25-49 years old, and 53\% of them are women. The questionnaire consists of attributes that created as indicators for the evaluation and cross-examining it with the literature. The assessment process is calculated based on a 5-point scale based on the fairness quality measurement. Analysis conducted through the triangulation technique between data, interview, and observation. This study assumes that the nature of attachment is set on the place attributes and function within HSL.

\section{RESULT AND DISCUSSION}

\subsection{Functional Attachment Form}

Findings from the interview (as presented in Table 3) indicate that the attachment has been stated in 5 (five) terms, including the length of engagement, level of familiarity, dependency, satisfaction, and sense of comfort. These responses indicate the significance of open space to strengthen economic and social activities. Findings also emphasize that the place depends on earning fixed income and business chances in daily. The satisfaction level from the respondents is mostly expressed regarding the facilities in open space in terms of its availability and diversity, street access, and the number of visitors. Meanwhile, the quality of physical and environmental comfort is revealed in terms of ease of accessibility and facilities for weather protection. Generally, people are happy with the physical improvement in the area, diversity of street vendors, and the number of visitors. Other respondents indicate the importance of location and pedestrian intensity in sustaining their attachment to HSL. 
Table 3 Indicators of functional attachment

\begin{tabular}{|c|c|}
\hline $\begin{array}{rr} & \text { Place } \\
\end{array}$ & Indicator \\
\hline Hiraq Square Lhokseumawe (HSL) & \\
\hline $\begin{array}{l}\text { The short-term relationship develops the attachment to place } \\
\text { Periodically visit, particularly on weekends and holidays, strengthen } \\
\text { familiarity. } \\
\text { Activities of street vendors. } \\
\text { Attraction in the area, such as playground lots. } \\
\text { Drinks and eat food as an attraction. } \\
\text { Keywords: Familiarity, Open space, Activities, Street Vendor, Social- } \\
\text { Relationships. }\end{array}$ & Engagement \\
\hline $\begin{array}{l}\text { High familiarity level with the place. } \\
\text { Imageable, can describe the area very well. } \\
\text { Concern on physical changes in the area. } \\
\text { Most street vendors know each other. } \\
\text { People engage with the street vendor frequently. } \\
\text { Keywords: Images, Changes, Street vendor, Events and attraction }\end{array}$ & Familiarity \\
\hline $\begin{array}{l}\text { A place to gain income. } \\
\text { The area is economically potential. } \\
\text { Length of engagement induces understanding over the space. } \\
\text { Opportunity to earn money develops an attachment to the area. } \\
\text { Attachment is due to recreation activities and to earn money. } \\
\text { Keywords: Daily income, Economic activities, Attachment, Control }\end{array}$ & Dependency \\
\hline $\begin{array}{l}\text { Satisfied with a low price of food and drinks offered in the area. } \\
\text { Many people to visit as attractions. } \\
\text { A special highlight of playing lots for children. } \\
\text { Keywords: Diversity, Sustainable life, Low price }\end{array}$ & Satisfaction \\
\hline $\begin{array}{l}\text { Happy with the place } \\
\text { Easy to get food, drinks and playing lots for children } \\
\text { Comfort access and walking through } \\
\text { Keywords: Facilities, Low Price, Accessibility, Walking }\end{array}$ & Comfort \\
\hline
\end{tabular}

\subsection{Functional Attachment Level}

Findings from the survey mostly designate positive feedback. Attachment to HSL was the main question in the questionnaire that needs to respond by respondents. Table 4 summarize that the average rate of 2.42 out of 4.0 expresses high response. This result represents a strong functional attachment to HSL, which is expressed by respondents. Regarding their purposes, most of the respondents approve that HSL is the best place, as well as perceive comfortable being there during the night.

Meanwhile, most respondents were not too satisfied with improvements in HSL, and they agreed that the effort to improve the area was very minimum. Feedback to statement number 1 (this place is better than other places in the city) indicates a strong functional attachment to HSL (value: 2.65). Figure 2 shown summarize positive feedback from respondents; they feel satisfied with HSL and assume it can function adequately compared to other places in Lhokseumawe.

Table 4 Functional attachment level to HSL based on the average rate

\begin{tabular}{|c|c|c|c|c|}
\hline \multirow{2}{*}{ Component } & \multirow{2}{*}{\multicolumn{2}{|c|}{ Statement }} & \multicolumn{2}{|c|}{ HSL } \\
\hline & & & Mean & Std. Dev \\
\hline $\begin{array}{l}\text { Functional Attachment } \\
\mathrm{N}=120\end{array}$ & \multicolumn{2}{|c|}{$\begin{array}{l}\text { This place is better than other places in the city (Best) } \\
\text { The comfort of location is sufficient (Comfortable) } \\
\text { The finest place to meet personal goals (Goals) } \\
\text { Vital place (Important) }\end{array}$} & $\begin{array}{l}2.65 \\
2.51 \\
2.32 \\
2.22\end{array}$ & $\begin{array}{l}.635 \\
.623 \\
.645 \\
.621\end{array}$ \\
\hline \multicolumn{2}{|c|}{ Response format: $1=$ strongly disagree, $4=$ strongly agree } & Average Rate & 2.42 & \\
\hline
\end{tabular}




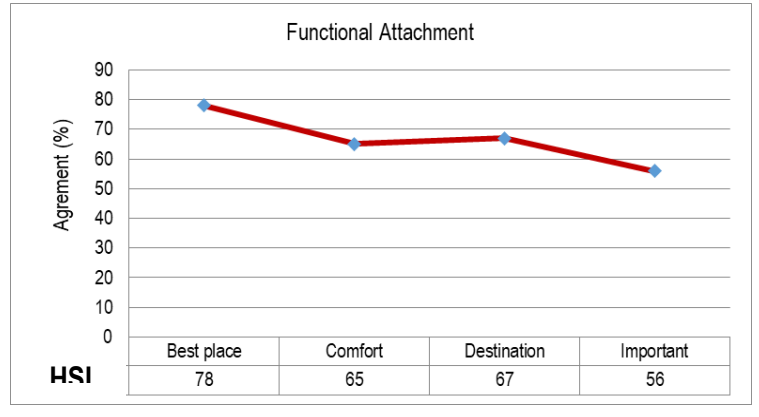

Figure 2 Percentage of functional attachment level to HSL $(\mathrm{N}=120)$

\section{CONCLUSION}

Both static and mobile respondents describe the significance of HSL as a place for economic' dependence as well as a spatio-temporal recreational place in the city, especially at night for children. Moreover, respondents agree that HSL is an accessible place for them and their family members regarding its adjacency between HSL to the road. Respondents also recommend HSL to become an alternative place in supporting their incomes at night compared to other open spaces in Lhokseumawe. Most of the static respondents argue that HSL becomes their dependence place to get personal needs and a major place for their livelihood. The form of functional attachment affects the attributes associated with the main function within HSL. In accordance with the sense of place' level recognized by Shamai [11], it can be concluded that the functional attachment level to HSL is between level 1 to level 3. Level 3 implicates the high level of commitment to HSL, which is represented by the faithfulness to daily economic activities, as well as a place to earn revenue and daily needs. However, most of the static respondents indicate their sense of place dependency and identity; meanwhile, mobile respondents were attached to the function which is offered by HSL. The results of this research are in line with the theory that the functional attachment level is diverse in pursuance of the user's role in the place.

\section{REFERENCES}

[1] B. Karsono, Deni, C.A. Fithri, Assessment of functional and emotional attachment in malacca riverfront promenade, Jurnal Teknologi (Sciences \& Engineering), vol. 78:5 (2016) pp. 153-157.

[2] E. Relph, Place and Placelessness. London: Pion Publication, 1976.

[3] D. Canter, The psychology of place. London: The Architectural Press Ltd, 1977.
[4] B. Karsono, S.S. Indira, Deni, The significance of uniqueness, comfort, security and safety to place attachment, Jurnal Teknologi (Sciences \& Engineering), vol. 78:5 (2016) pp. 179-183.

[5] I. Altman and S. Low, Ed. Place Attachment. New York: Plenum Press, 1992.

[6] M. V. Giuliani, Theory of attachment and place attachment, In Psychological Theories for Environmental Issues, M. Bonnes, T. Lee and M. Bonaiuto, Ed. Aldershot, UK: Ashgate Publishing Company, pp. 137-170, 2003.

[6] M. Bonnes and G. Secchiaroli, Environmental Psychology: A Psychosocial Introduction. London: Sage Publications, 1995.

[7] D. M. Hummon, Community attachment: Local sentiment and sense of place, In Place attachment, I. Altman and S. Low, Ed. New York: Plenum Press, 1992.

[8] M. Carmona, T. Heath, T. Oc, and S. Tiesdell, Public Places - Urban Spaces, the Dimensions of Urban Design. Oxford: Architectural Press, 2003.

[10] H. M. Proshansky, A. K. Fabian, and R. Kaminoff, Place identity: physical world socialisation of the self, giving place meaning, in Readings in Environmental Psychology, L. Groat, San Diego: Academic Press, pp. 87-113, 1995.

[11] S. Shamai, Sense of place: An empirical measurement, Geoforum, vol. 22(3) (1991) pp. 347358 ,

[12] C. R. Stedman, Is it really just a social construction? The contribution of the physical environment to sense of place, Society and Natural Resources, vol. 16 (2003) pp. 671-685.

[13] H. M. Proshansky, W. H. Ittelson, and L.G. Rivlin, Environmental Psychology: People and Their Settings. New York: Holt, Rinehart and Winston, 1976.

[14] R. Gifford, Environmental Psychology: Principles and Practice. Boston: Allyn and Bacon, Inc., 1987.

[16] K. Lynch, The Image of the City. Massachusetts: MIT Press. 1960

[17] R. von Eckartsberg (1998) Introducing existentialphenomenological psychology, In Phenomenological Inquiry in Psychology, R. Valle, Ed. New York: Plenum, pp. 3-20. 